\title{
Effect of Public Investment on Private Investment: Evidence from Ethiopia
}

\author{
Temesgen Merga ${ }^{1}$ \\ ${ }^{1}$ Ethiopian Police University, Ethiopia
}

\begin{abstract}
Background: This study examined the effect of public investment on private investment and their relative effects on Ethiopia economic growth. Methodology: The study employed the Autoregressive Distributed Lag (ARDL) bounds testing approach to test the study objectives. Findings: The empirical results revealed that public investment has a crowding-in effect on private investment in the long run which means, public investment stimulates private investment in the long run. However, the study revealed that public investment has a crowding out effect on private investment. In the other word, public investment has no direct impact on economic growth in the long run. However, private investment has a significant positive impact on economic growth in the long run while it is negatively related to economic growth in the short run. This suggests that private investment positively contributes to economic growth more than public investment. In addition, economic growth is positively associated with private investment although it is statistically insignificant in the long run. This implies that it is prudent for policy makers not to cut back on the efficient component of public investment and increase infrastructural public investment to a level that promotes private investment in the long run thereby indirectly fostering economic growth.
\end{abstract}

Key words: Private investment, public investment, crowding-in, crowding-out, economic growth

\section{Introduction}

The causal relationship between the public sector and private sector investment is a central issue in both macroeconomics and development economics. A noteworthy question raised here is what relationship they do have and which type of investment more fosters the economic growth of a certain country. The linkage between public investment and private investment, and their relative contribution to economic growth is a controversial issue from both theoretical and empirical perspectives (Emana; 2021). There are two opposite ideas ongoing regarding the issue of public investment and private investment and economic growth.

On the one hand, the case of substitutability (negative linkage) of the two types of investment can occur in different situations. Public sector investment for instance may directly negatively affect private investment through competition of scarce resources (Orogwu et al.; 2021). The public sector will compete with the private sector for funds in the capital markets, causing the interest rate to rise in order to finance its investment (see, (Erden and Holcombe; 2006; Sen and Kaya; 2014)). This demand of the public sector for funds has an indirect negative impact on private sector investment through the interest rate. Public enterprises may also produce goods and services which compete directly with the private sector so that the two forms of investment become substitutes (see, (Khan and Kumar; 1997; Sen and Kaya; 2014; Makuyana and Odhiambo; 2018). In addition, if the public investment is financed by increasing taxes, it may further exacerbate distortions in the economy and increase the costs of inputs, leading to an adverse effect on expected output growth and private investment, which has an indirect adverse effect to private investment (Khan and Kumar; 1997). For this reason, the amount of loanable funds available for private firms will reduced, hence, lowering private capital formation, meanwhile, causing a crowd out effect of private investment 
by public investment.

On the other hand, there may be complementary relationships between public and private investment. Public investment can create conducive conditions for private investment in terms of infrastructure, which reduces private production costs. Public sector can promote the private sector, for instance, by providing infrastructure such as roads, highways, sewer and water systems, and power plants, often resulting in a reduction in costs facing the private sector and raising the productivity of private capital (Erden and Holcombe; 2006). The availability of such core infrastructural goods and services reduces private sector sunk costs and increases total productivity and profitability of private sector. Better facilities increase the productivity of private investment and reduce the cost of production of the private sector which has a positive impact on the profitability of the private investment. This will also indirectly cause positive affect on private investment through its provision of outputs which is used as inputs for private companies (Khan and Kumar; 1997). In addition, the public sector may also initiate private investment through its demand private sector output.

There is also empirically no consensus agreement upon the relationship between the public and private investment and growth process even though voluminous empirical studies appeared in accord. As for the first empirical evidence, many studies in developing countries show evidence that public investment positively affects private investment and as well as economic growth (see, (Khan and Reinhart; 1990; Erden and Holcombe; 2006; Hassan et al.; 2006; Dreger and Reimers; 2015; Ouedraogo et al.; 2019)). In addition, other studies indicate the existence of the positive relationship (crowding in effect) between public and private investment in the long run equilibrium rather than short run (see, (Canh and Phong; 2017; Nguyen and Trinh; 2018)). As for the second empirical evidence, some cases indicate that public investment negatively affects private investment and/or has little or even no impact on economic growth (see, (Dash; 2016; Ghani and Din; 2006)). As a result, it seems that empirical results are country and a study time period specific as well as the model used for the study may also affect the empirical results. Hence, study is needed to identify the real effect of public sector investment on private sector investment and their relative contribution to economic growth by choosing an appropriate econometric approach and relevant period of time.

The rest of the paper is organized as follows. Section 2 sheds some light on the existing literature and trends of private investment, public investment, and economic growth in Ethiopia. This is followed by the definition of the data used and the methodology employed in the study in section 3. Section 4 briefly presents and discusses the major findings of the study and talks about the reliability of the model employed in the study. Conclusions and Implications are presented in Section 5 , at the end of the paper.

\section{Literature Review}

\subsection{Theoretical Review}

The production function is one of the key concepts of mainstream neoclassical theories which is used to define marginal products and to distinguish allocated efficiency. The focus of Economics is also the study of how to efficiently use scarce resources so as the output is produced at a higher rate of margin through production function. Cobb-Douglas production function represents the technological relationship between the two economic inputs, particularly physical capital and labor, and the amount of output that can be produced by those inputs. However, the issue may arise about the nature of the capital formation, which component of capital formation is economic growth driven whether the capital formation is made by the public sector or capital formation made by the private sector. The reason is that sustainable growth may not be achieved with an inadequate investment policy.

Neo-Classical does not believe in government intervention and argue that the market can clear since supply can alway creates it own supply. With regards to investment, Neoclassical economists believes that public investment negatively affects (crowds-out) private investment in such a way as competing for funds, increasing the interest rate, imposing more taxes to get more funds, producing the same products as that of private investment, among others. On the other hand, the Keynesian believes in the need and power of government in stabilizing the market. They believes that the market will always fails to create its own demand leading to fall in aggregate demand as witnessed during the great depression. They believed that public investment positively affects (crowds-in) private investment in such a way by providing relevant infrastructures, more willing to make higher-risk investments than the private sector, in which public investment output is used as input for private investment at an affordable price, among others. Lastly, the Ricardian view states that there is neither a positive nor negative relationship between public and private investments. Because, tax cuts now by the government may be imposed more in the future in order to finance its debt due to tax cuts, which means, tax burden from now is transferred to the near future.

\subsection{Empirical Review}

Investigations about the linkage between public investment and private investment and the growth process have been a series of debates among policymakers and academicians. A comprehensive study has been carried out in different countries and groups of countries, and the results are quite not the same. Empirical studies have used various approaches and various time series to investigate the impact of public investment on private investment and in the process of economic growth. In this regard, some studies show positive effects of public investment on private investment often appeared in developing countries or emerging economies (see, (Khan and Reinhart; 1990; Khan and Kumar; 1997; Erden and Holcombe; 2006; Hassan et al.; 2006; Islam et al.; 2018; Ouedraogo et al.; 2019)).

On the other hand, some studies show that competition between public investment and private investment leads to a negative relationship between them i.e. the former one crowds-out the latter one (see, (Dash; 2016; Ghani and Din; 2006)). On the other hand, some other researchers argue that there is no sufficient evidence to conclude on the existing relationship, rather the relationship is economic term's dependent. There may be positive relationship in the short run and negative in long run or vice versa or has insignificant evidence to conclude (see, ((Naqvi and Tsoukis; 2003; Dreger and Reimers; 2015; Canh and Phong; 2017; Nguyen and Trinh; 2018; Makuyana and Odhiambo; 2018, 2019; Ouedraogo et al.; 2019)).

Furthermore, Member (2015) studied the relationship between private investment and major determinants of private investment in Ethiopia. Results of his study indicated that public investment has a crowding-out effect on private invest- 
ment both in the long run and in the short run. In contrast to the study of Member (2015), a resent study by Ouedraogo et al. (2019) founds a crowding-in effect of public investment on private investment in sub-Saharan Africa countries in general and Ethiopia in particular. In addition, empirical findings of many studies in developing countries show that there is a positive relationship between public and private investment because both of the investments are not strong enough to compete with each other. Pertinent to this, this study aims to shed some light on reconciling the relationship between public and private investment accompanied by economic growth in Ethiopia empirically.

\subsection{Trends of Public and Private Investment in Ethiopia}

Total investment in Ethiopia has sharply been increasing since 1993 through 2018. Ethiopia's gross domestic investment as a share of GDP has re markedly improved over the years in contrast with the trend observed in most Sub-Saharan Africa countries. Private investment can boost employment and productivity, transfer technology, and could bring foreign exchange so that the reserve will be improved. As a result, the high share of investment in Ethiopia compared to SSA on average is due to the creation of an enabling environment, especially for the participation of the private sector along with the public sector aggressive investments in infrastructure and social services (WB 2013). Nevertheless, Ethiopia's private investment share is yet at its infant level.

Ethiopia has been making fast growth for the past two decades and especially registering a GDP growth rate of $10.4 \%$ per annum during the periods 2004- 2018. The most important factors that contributed to the economic growth of Ethiopia are agricultural modernization, the development of new export sectors, strong global commodity demand, and governmentled development projects. The big push of public investmentled development has delivered positive returns but the development of a strong and vibrant private sector is needed to sustain the high growth according to the report. Therefore, it is not only the total level of investment that matters for growth but also a particular focus on private investment is a crucial concern for policymakers. In line with this, in Ethiopia, since 2018 when the Ethiopian Government launched a privatization policy, the impact of government investment on private investment and economic growth has become a central issue in policy debates among policymakers and academicians. As it is seen from the graph below, one can allegedly see that private investment and economic growth don't have a consistent relationship. Figure 1 revealed the trends of private investment, public investment, and the growth process in Ethiopia since 1990-2018. When investment is disaggregated into its components, both the public and private investments in Ethiopia have jointly been increasing especially since 2000 until 2016 . In particular, the public investment escalated from 6.2 percent as a share of GDP in 1994 to 23 percent as share of GDP in 2017 but declined to 21.6 percent in 2018. On the other hand, private investment increased rapidly from 5.7 percent in 1996 to 21 percent in 2016 but surprisingly fell to 12 percent as a share of GDP in 2018. On average both the public investment and private investments are almost similar, registering 13.3 percent and 12.6 percent as a share of GDP, respectively. As can be observed in Figure 1, there is almost a positive relationship between public and private investment, which means, private investment seems to follow the evolution of public investment over time.

\section{Data and Methodology}

\subsection{Data and Source}

The annual data employed in this study is found from National Planning and Development Commission (NPDC) of Ethiopia and National Bank of Ethiopia (NBE). The variables used in this study include private investment, public investment, the real rate of economic growth, and real interest rate. For purpose of estimation, the following series were used: GDP at constant basic prices which is at 2003 base year $(\mathrm{Y})$; general government gross fixed capital formation as share GDP as a public investment (GI); gross fixed capital formation of the private sector as a share of GDP as private investment (PI); the real interest rate calculated as the difference between the lending rate and inflation rate (R). Given data constraints, the study employed data between 1993 to 2018, a period consider sufficient for long-run analysis and to ensure the quality of the data, only data public available and released by the appropriate authority is used in the analysis and where such data is not available, the study simply discard the series in question.

\subsection{Estimation Technique}

Developments in econometric have allowed the researchers to not only examine the extent to which variables are nonstationary, but also whether they grow together over time and converge to their long-run relationship (Ghani and Din; 2006). Long-run linear relationships among variables in the presence of short-run deviations from the long-run equilibrium are checked using co-integration test. In the case of non-stationary series with a unit root, the first differencing of variables provides the appropriate solutions to ensuring the series are weakly stationary (Tonuchi and Onyebuchi; 2019).

This paper employs the newly developed ARDL bounds testing framework that was initiated by(Pesaran and Shin; 1999) and later popularized by (Pesaran et al.; 2001), which is built for the same purpose. The approach has recently been credited for its advantages over the traditional co-integration techniques such as the full maximum likelihood-based approach by Johanson (1991) and the residual-based approach byDreger and Reimers (1987). There are couples of advantages of using ARDL bounds approach over other co-integration tests. Firstly, the ARDL approach is ideal even with a small sample while the traditional co-integration techniques are sample size sensitive, which is the case in this study. Secondly, it does not restrict the variables of interest to be integrated of the same order (Pesaran et al.; 2001). It can be applied when the variables are a mixture of integrated of order zero I(0), one I(1) or partially integrated. Thirdly, the ARDL estimates the long-run relationship using a single reduced form equation, unlike the traditional co-integration approach that employs a system of equations (Makuyana and Odhiambo; 2018). Finally, It doesn't restrict the variables of interest to be all endogenous i.e. it is applicable to the mixture of endogenous and exogenous variables and it provides long-run estimates that are unbiased. The ARDL bounds representation of the effect of public investment on private investment model is specified as follows:

$$
\begin{array}{r}
\Delta P I_{t}=\beta_{0}+\sum_{i=1}^{p} \beta_{1} \delta P I_{t-i}+\sum_{i=0}^{p} \beta_{2} \Delta G I_{t-i}+ \\
\sum_{i=0}^{p} \beta_{3} \Delta Y_{t-i}+\sum_{i=0}^{p} \beta_{4} \Delta R_{t-i}+\sum_{i=0}^{p}+\alpha_{1} P I_{t-1}+ \\
\alpha_{2} G I_{t-1}+\alpha_{3} Y_{t-1}+\alpha_{4} R_{t-1}+\mu_{t}
\end{array}
$$




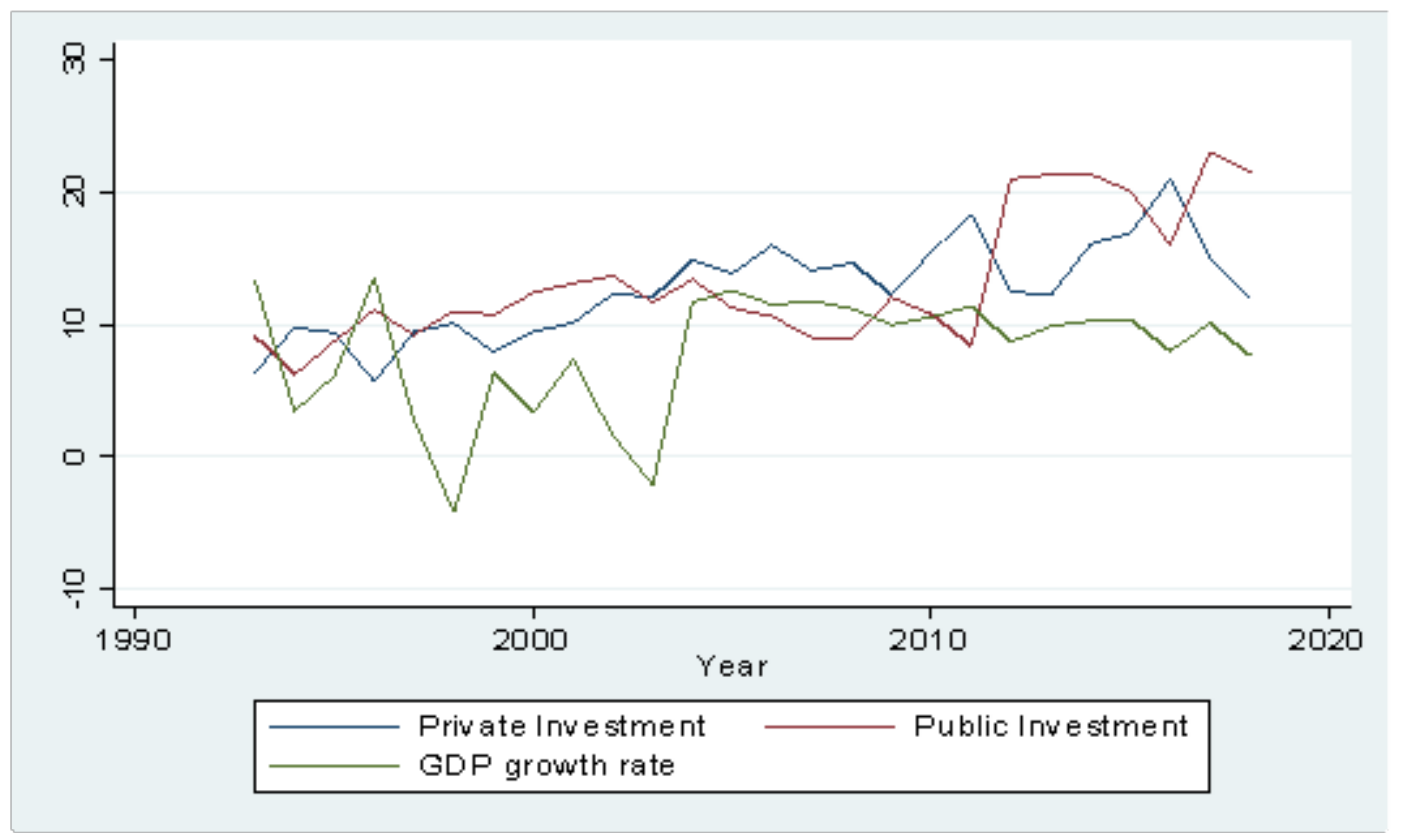

Figure 1. Trends of public investment, private investment and economic growth

Table 1. Unit root test (Augmented Dickey-Fuller test)

\begin{tabular}{|c|c|c|c|c|}
\hline & $\frac{\text { ADF Approach }}{\text { Integrated of Zero, I(o) }}$ & & Integrated of one, I(1) & \\
\hline Variables & with trend & without trend & with trend & without trend \\
\hline LnPI & -2.763 & $-3.680 * *$ & $-6.352 * * *$ & $-6.282 * * *$ \\
\hline LnGI & -1.730 & -3.012 & $-6.860 * * *$ & $-6.662 * * *$ \\
\hline LnY & -1.067 & -2.743 & $-6.267 * * *$ & $-6.454 * * *$ \\
\hline LnR & $\begin{array}{l}-4.142^{* * *} \\
\text { PP Approach }\end{array}$ & $-4.280 * *$ & $-7.335^{* * *}$ & $-7.168 * * *$ \\
\hline LnPI & $-2.719^{*}$ & $-3.642^{* *}$ & $-9.542^{* * *}$ & $-13.567 * * *$ \\
\hline LnGI & -1.520 & -3.012 & $-7.402 * * *$ & $-7.152 * * *$ \\
\hline LnY & $-4.022 * * *$ & $-4.687 * * *$ & $-18.503 * * *$ & $-17.862 * * *$ \\
\hline LnR & $-4.142 * * *$ & $-4.282 * *$ & $-12.997 * * *$ & $-12.580 * * *$ \\
\hline
\end{tabular}

Significance is indicated as follows: $* * *, * *$ and $*$ for $1 \%, 5 \%$ and $10 \%$ respectively.

Where, PI (the dependent variable), is the gross fixed capital formation by the private sector (a proxy for private investment); GI is the gross fixed capital formation by the government (a proxy for public investment); $\mathrm{Y}$ is the growth rate of real gross domestic product (a proxy for economic growth); $\mathrm{R}$ is the annual rate of real interest; $\beta_{0}$ is the intercept; $\beta_{1}$ to $\beta_{4}$ and $\alpha_{1}$ to $\alpha_{4}$ are short-run and long-run elasticities, respectively, of private investment model with respect to above identified variables; $\mu_{t}$ is the white noise residuals; $\Delta$ is the difference operator; and $\mathrm{p}$ is the lag length.

The null hypothesis to be tested here is: $H_{0}=\alpha_{1}=\alpha_{2}=\alpha_{3}=$ $\alpha_{4}=0$, which indicates the non-existence of long run relationship against $H_{1}$ : not $H_{0}$ (at least one of the coefficients is different from zero) which indicates the existence of long run relationship.

Similarly, the ARDL representation of the relative contribution of public and private investment to the economic growth model is specified as follows:

$$
\begin{array}{r}
\Delta Y_{t}=\beta_{0}+\sum_{i=1}^{p} \beta_{1} \delta Y_{t-i}+\sum_{i=0}^{p} \beta_{2} \Delta G I_{t-i}{ }^{+} \\
\sum_{i=0}^{p} \beta_{3} \Delta P I_{t-i}+\sum_{i=0}^{p} \beta_{4} \Delta R_{t-i}+\sum_{i=0}^{p}+\alpha_{1} Y_{t-1}{ }^{+} \\
\alpha_{2} G I_{t-1}+\alpha_{3} P I_{t-1}+\alpha_{4} R_{t-1}+\mu_{t}
\end{array}
$$

Where, $\beta_{1}$ to $\beta_{4}$ and $\alpha_{1}$ to $\alpha_{4}$ are short-run and long-run elasticities, respectively, of output growth model with respect to above identified variables; $\mu_{t}$ is a white noise residual; and all other variables are as defined earlier in equation (1). The null hypothesis to be tested here is: $H_{0}=\alpha_{1}=\alpha_{2}=\alpha_{3}=\alpha_{4}=0$, which indicates the non-existence of long run relationship against $H_{1}$ : not $H_{0}$ (at least one of the coefficients is different from zero) which indicates the existence of long run relationship. 
Table 2. ARDL bounds test for co-integration of both models

\begin{tabular}{llll}
\hline Dependent variable & Function & F Statistic & Co-integration Status \\
\hline LnPI & F(LnPI|LnGI,LnY,LnR) & $11.23^{* * *}$ & Co-integrated \\
LnY & F(LnY|LnPI,LnGI,LnR) & $6.18^{* * *}$ & Co-integrated \\
& Asymptotic critical values & & \\
Pesaran et al. (2001) & $1 \%$ bounds & $5 \%$ bounds & $10 \%$ bounds \\
& I(0) I(1) & I(0) I(1) & I(0) I(1) \\
& 4.295 .61 & 3.234 .35 & 2.723 .77
\end{tabular}

AIC $(1,3,0,1)$ Respective lag length of the variables Note: ***, ** and* denotes statistical significance at $1 \%$ and $10 \%$ level, respectively. Source: Compiled by the author.

Table 3. ARDL bounds test for co-integration of both models

\begin{tabular}{|c|c|c|c|}
\hline VARIABLES & (A)ECT & (B)Long-term & (C)Short-term \\
\hline & For Model 1 & & \\
\hline D.LnGI & & & $-0.808 * * *(0.213)$ \\
\hline LD.LnGI & & & $-0.658 * *(0.242)$ \\
\hline L2D.LnGI & & & $0.246(0.157)$ \\
\hline D.LnR & & & $0.130 * * *(0.0420)$ \\
\hline LnGI & & $0.565 * * *(0.176)$ & \\
\hline $\operatorname{LnY}$ & & $0.0171(0.0714)$ & \\
\hline LnR & & $-0.292 * * *(0.0864)$ & \\
\hline L.LnPI & $-0.590 * * *(0.192)$ & & \\
\hline \multirow[t]{2}{*}{ Constant } & & & $1.207 * * *(0.376)$ \\
\hline & For Model 2 & & \\
\hline LnPI & & $1.459 * *(0.589)$ & \\
\hline LnGI & & $-0.469(0.475)$ & \\
\hline LnR & & $0.0371(0.172)$ & \\
\hline L.LnY & $-0.011 * *(0.213)$ & & \\
\hline D.LnPI & & & $-1.864 * *(0.810)$ \\
\hline LD.LnPI & & & $-1.607 * *(0.615)$ \\
\hline Constant & & & $0.101 * *(1.585)$ \\
\hline Observations & 23 & 23 & 23 \\
\hline R-squared & 0.837 & 0.837 & 0.837 \\
\hline Testing methods & model 1 & model 2 & Critical Values \\
\hline D-Watson test & 2.02 & 1.83 & 0.89 \\
\hline Breusch-Godfrey & 0.56 & 0.26 & 0.05 \\
\hline Normality & 0.12 & 0.44 & 0.05 \\
\hline Heteroskedasticity & 0.40 & 0.40 & 0.05 \\
\hline
\end{tabular}

Note: 1) $* * *, * *$ and $*$ denotes statistical significance at $1 \%, 5 \%$ and $10 \%$ level, respectively; 2) Standard errors in parentheses; 3 ) D. is first difference operator; 4) L. is lag operator. Source: Compiled by the author.

\section{Empirical Analysis}

Econometric analysis of time series is highly sensitive to the number of lags included in the analysis. Thus, it needs priority to determine the number of lag lengths to be included. The number of lags to be included in the stationary test is determined by the given information criterion in the model, at which the generated value is minimum. Therefore, the maximum lag length for the model is 3 , which is automatically determined at the lower values of the information criterion just like AIC and SBIC.

\subsection{Stationarity Test}

Before conducting the empirical analysis, it is important that all the variables used be subjected to stationary test either at the level or at the first difference in order to undertake further analysis. Estimation of the model using time series data techniques without testing for stationary may lead to spurious regression which leads to false conclusions. This is important in order to ensure that no variable is integrated of order two or higher so as ascertaining ARDL bounds procedures. The study employs the Augmented Dickey-Fuller (ADF) and the Phillips
Perron (PP) unit root testing techniques. The lag length in ADF is automatically selected by Akaike information criterion (AIC) and Phillips-Perron (PP) truncation lag is selected automatically by the Newey-West bandwidth.

The results of both ADF and PP unit root tests as revealed in Table 1 show that all the variables are integrated of order zero and order 1 . Now, it is possible to apply the ARDL bounds test since the variables are either integrated of order zero, $\mathrm{I}(0)$ or integrated of order one, I(1).

\subsection{Estimation and Discussion of Results}

Estimation using the ARDL bounds testing framework is based on two steps. The first step involves testing co-integrating relationships among all variables in each ARDL model. The second step involves estimating the long run and short run coefficients of each ARDL model by ordinary least square (OLS) (Tonuchi and Onyebuchi; 2019). The short run dynamics are captured by the first differenced variables in each error correction model. The bounds F-test for co-integration in both private investment and economic growth equations (Table 2) indicate that the variables share a long-run relationship since 


\begin{tabular}{l|l|l|l}
\hline Null Hypothesis: & Obs & F-Statistic & Prob. \\
\hline LGI does not Granger Cause LPI & 23 & 3.37117 & $0.0447^{* *}$ \\
LPI does not Granger Cause LGI & & 0.19232 & 0.9001 \\
LY does not Granger Cause LPI & 23 & 0.07591 & 0.9721 \\
LPI does not Granger Cause LY & & 4.86924 & $0.0136^{* *}$ \\
\hline
\end{tabular}

Table 4. Pairwise granger causality test results

the value is larger than the given upper boundary significance.

Since the variables are co-integrated, the next step is estimating the long run and short run coefficients of the ARDL bounds model. In estimating the coefficients, the first difference of the endogenous variable is regressed on a one period lag of the co-integrating equation using maximum likelihood estimation method. The short-run dynamics are captured by the first differenced variables while the log run is captured by level variables in the error correction model. Column A (the error correction estimates presented in the Table 3) shows that the error correction term (ECT) coefficients of the given equations are statistically significant and have negative signs, as expected. This implies that convergence is achieved in the longrun in case shock is revealed in the previous year i.e. the series cannot drift too far apart from the long run equilibrium. In line with this, private investment adjusts itself faster to its long run dynamics than economic growth in case shocks occur in the previous year.

Column B presents the long-run results of the models while the short-run results are presented in the same table under column C. The results show that public investment has a statistically significant positive effect on private investment in the long run while it negatively affects private investment in the short run. A one percent increase in public investment stimulates private investment by 0.57 percent in the long run while one percent increase in public investment is associated with 0.81 percent decline in private investment in the short run. Not only current, but previous one period lagged public investment undertaken is also negatively associated with current period private investment with statistically significant coefficient. This suggests that the private sector is waiting for a good business environment to be created by the public sector, which reduces production costs to the private sector. This confirms the study done by Ouedraogo et al. (2019) while it is thoroughly counter to Member (2015) in case of Ethiopia. The estimate from the above ARDL bounds technique also compares well with the empirical results found in the literature (see, (Makuyana and Odhiambo; 2018, 2019; Ouedraogo et al.; 2019).

On the other hand, public investment has a negative impact on the economic growth in the long run even though it is statistically insignificant. However, since the estimate is insignificant at a given level, one cannot make too much conclusion of the sign of this coefficient. Although the estimated result measures the direct effect of public investment which is insignificant at a given significance, it may have an indirect impact on the growth process through private investment. In this regard, public investment might have an indirect positive impact on economic growth through private investment since it exerts direct positive impact on private investment in the long run. For example, if private and public investments are complementary, it encourages private investment through infrastructure expenditure (Khan and Reinhart; 1990). Then, private investment exerts a positive impact on the growth process. However, the dynamics of public investment has no immediate effect on economic growth in the short run.
The results of the other variables indicate that real interest rate is positively associated with private investment in the short run, but in the long run it has negative effects. In line with this, one percent increase in real interest rate is associated with 0.13 percent rises in private investment in the short run while it causes a 0.29 percent decline in private investment in the long run in Ethiopia. Hence, this rise in real interest rate is not a lasting incentive to private investment, because private agents prefer saving to investing more in the long run if a raise in it has continual. In the other case, real interest rate has no direct impact on economic growth since the estimate is statistically insignificant. It might suggest that it takes time for the deposited money to be converted to real investment.

Economic growth has a positive effect on private investment, but statistically insignificant in the long run while it is a negative effect in the short run regardless of the econometric model. Pertinent to this, it is impossible to give a solid conclusion regarding this variable. However, it can be said that the growth process in Ethiopia has no direct effect on economic growth, which in itself is an important result. Furthermore, this supports the theory of accelerator investment hypothesis which says that an increase in output may have no (even can have negative) impact on investment in the short run, but has positive impact in the long run. It says an output has a reciprocal relationship with investment. In the other direction, private investment has a positive significant impact on economic growth in the long run while it has a negative impact in the short run. This suggests that private investment could not automatically exert positive impact growth process, which implies that it takes time for private investment to adjust itself and to contribute positive impact to economic growth.

Furthermore, it can be said that private investment positively contributes more to economic growth than public investment. These results of the relative contribution of public and private investments to output growth compare well with the empirical evidence reported by Feleke (2013). Many famous scholars also say that private investment has a much larger impact than public investment in developing countries (see, (Khan and Kumar; 1997; Khan and Reinhart; 1990; Barro; 1991). This might also be due to the government's large expenditure on non-capital wealth which is aimed at the present consumption rather than long-run capital formation, which leads to the imposition of higher taxation and/or competes with the private sector for scarce resources to finance its expenditure. Moreover, the results might depend on the econometric model used (see, (Naqvi and Tsoukis; 2003; Ouedraogo et al.; 2019)).

\subsection{Granger Causality Test}

Since co-integration exists, there is needs to test for the direction of causality by using the granger method. According to Dreger and Reimers (1987), if a co-integrating relationship is identified, then causality must exist in at least one direction. It helps to identify the direction of causality so that it is easy to 
know the policy variable in the econometric model. The Table 4 presents the pairwise causality test among the variables of interest.

The results show that there is uni-directional causality between the displayed variables. This indicates the evidence that previous values of public investment have an impact on current and future values of private investment since it is statistically significant. Then, it is called a public investment granger causes private investment. However, there is no evidence that private investment can granger causes public investment since a test is statistically insignificant. This implies that public investment is weakly exogenous to private investment, which means public investment leads to private investment, but not vice versa.

For the second variable of interest, previous values of private investment have an impact on current and future values of economic growth since the test is statistically significant. Thus, private investment granger causes economic growth. But, there is no evidence that economic growth Granger causes private investment since the test result is insignificant. In general, therefore, the public investment seems to be an exogenous variable which means that public investment is a policy variable. It suggests that a lack of public investment could lead to direct restrictions on private investment and indirect restrictions on economic growth through private investment. Thus, an increase in proper public investment policy exerts a positive impact on private investment thereby fostering economic growth.

\section{Conclusions}

This study empirically examined the effect of public investment on private investment and their relative contribution to economic growth in Ethiopia for the period of 1993 to 2018 . The study employed the ARDL bounds testing approach. The empirical results of this study revealed that public investment stimulates private investment, which means a crowding-in effect in the long run, while it is a crowding-out in the short run. In the short run, not only the current period of public investment but also an increase of previous year public investment retards private investment. On the other hand, public investment has no direct impact on economic growth as the estimated coefficient measure of the public investment is insignificant at a given significance. However, it might exert a positive impact on the growth process through private investment in the long run.

The other variable, the real interest rate, has a negative effect on private investment in the long run while it is positively associated with private investment in the short run. In the short run, rising real interest rates might encourage lenders to save sufficient money so that private sectors can easily get funds to invest more. Unfortunately, this rising cost of funds retards the ability of the private sector to be sustained with the cost, which actually declines private investment in the long run. On the other model, the real interest rate has insignificant positive effects on economic growth, which implies that real interest rate has no direct impact on economic growth, but it might have indirect negative impact on output growth through private investment in the long run.

Economic growth is positively related to private investment although it is statistically insignificant in the long run. However, it has no immediate effect on private investment in the short run. In the other direction, private investment has a significant positive impact on economic growth in the long run while it is negatively related to economic growth in the short run. This confirmed that there is a uni-directional effect, which is private investment could affect economic growth while it is not vice versa. Based on these results, it can be concluded that private investment contributes to economic growth more than public investment in Ethiopia. However, the contribution to the economic growth of public investment can be enhanced by focusing on growing the public investment policy which more stimulates private investment. There is also a complementary relationship between the two components of investment in the long run.

Thus, it is prudent for policymakers not to cut back on the efficient component of public investment, but, raising the infrastructural public investment to a level that promotes private investment in the long run thereby indirectly fostering the economic process. Then, private sectors invest more resources in those profitable business environments. Government should have to pay attention to formulating policies in the provision of more financial resources for the private sectors, so that it is important to stimulate private sector investment directly and boost output growth indirectly through private investment activity. However, this study may have limitations as do many empirical studies although it is done to ensure the results are robust and reliable to my best knowledge. This may be due to the non-availability of data on some economic variables, which may the econometric models has been underspecified. The other limitation may be the shortness of time frame although the econometric model applied here gets credit of appropriateness for the case. Therefore, it would be interesting to find out if the empirical results on the crowdingin/-out effect would change fundamentally in future studies on the availability of some variables like infrastructural and non-infrastructural public investments in Ethiopia.

\section{Competing Interests}

Author declare no competing interests.

\section{References}

Barro, R. (1991). Economic growth in a cross-section of countries, The Quarterly Journal of Economics 106(2): 407-443.

Canh, N. T. and Phong, N. A. (2017). Linkage between public (state sector) investment, private investment and economic growth: Evidence from vietnam, International Research Journal of Finance and Economics 1: 164.

Dash, P. (2016). The impact of public investment on private investment: Evidence from india, The Journal for Decision Makers 41(1): 288-307.

Dreger, C. and Reimers, H. E. (1987). Cointegration and error correction: Representing, estimation and testing, Econometrica 55(2): 251-276.

Dreger, C. and Reimers, H. E. (2015). The impact of public investment on private investment in the euro area, Vierteljahrshefte zur Wirtschaftsforschung 84(1): 183-193.

Emana, D. (2021). The relationship between budget deficit and economic growth: Evidence from ethiopia, Applied Journal of Economics, Management and Social Sciences 2(2): 10-15.

URL: https://nokspublishing.com/index.php/AJMSS/article/view/12

Erden, L. and Holcombe, R. G. (2006). The linkage between public and private investment: a co-integration analysis of a panel of developing countries, Eastern Economic Journal 32: 476-492.

Feleke, E. (2013). The Role of Private Investment to the Economic 
Growth of Ethiopia, Addis Ababa, Addis Ababa University.

Ghani, E. and Din, M. u. (2006). The impact of public investment on economic growth in pakistan, The Pakistan Development Review 45(1): 87-98.

Hassan, S., Othman, Z. and Karim, M. Z. (2006). Private and public investment in malaysia: A panel time series analysis, International Journal of Economics and Financial Issues 1(1): 199210.

Islam, M., Hossain, A. and Tareque, M. (2018). Impact of public and private investment on gdp growth in bangladesh: Crowding-in or out?, Global Journal of Human-Social Science: Economics 18(1): 1-9.

Johanson, S. (1991). Estimation and hypothesis testing of cointegration vectors in gaussian vector autoregressive models, Econometrica 52(1): 389-402.

Khan, M. and Reinhart, K. (1990). Private investment and economic growth in developing countries, World Development 18(1): 19-27.

Khan, M. S. and Kumar, M. S. (1997). Public and private and the growth process in developing countries, oxford Bulletin of Economics and Statistics 59(1): 0305-9049.

Makuyana, G. and Odhiambo, N. (2018). Public and private investment and economic growth in zambia: A dynamic approach, International Economics 71(1): 503-526.

Makuyana, G. and Odhiambo, N. (2019). Public and private investment and economic growth in malawi: an ardl-bounds testing approach, Economic Research 32(1): 673-689.

Member, K. (2015). Public and private investment analysis in ethiopia, Research Journal of Economics and Business Studies 04: 26-38.
Naqvi, N. and Tsoukis, C. (2003). Does public investment crowd out private investment? evidence on investment and growth in asia, 1971-2000, European Research Studies 6: 58-72.

Nguyen, C. T. and Trinh, L. T. (2018). The impacts of public investment on private investment and economic growth: Evidence from vietnam, Journal of Asian Business and Economic Studies 25: 15-32.

Orogwu, D., Fakoyode, S., Itopa, M. and Abdulbasit, A. (2021). Sectoral analysis of foreign direct investment and growth in nigeria, Applied Journal of Economics, Management and Social Sciences 2(1): 33-41.

URL: https://nokspublishing.com/index.php/AJMSS/article/view/4 Ouedraogo, R., Sawadogo, H. and Sawadogo, R. (2019). Impact of public investment on private investment in sub-saharan africa: Crowding in or crowding out?, African Development Review 31(1): 318-334.

Pesaran, H. and Shin, Y. (1999). An Autoregressive Distributed Lag Modelling Approach to Cointegration Analysis, University of Cambridge Press.

Pesaran, H., Shin, Y. and Smith, R. (2001). Bounds testing approaches to the analysis of level relations, Journal of Applied Econometrics 16(1): 289-326.

Sen, H. and Kaya, A. (2014). Crowding-out or crowding-in? analyzing the effects of government spending on private investment in turkey, PANOECONOMICUS 61(6): 617-630.

Tonuchi, J. and Onyebuchi, N. (2019). Economic diversification in nigeria: The role of agriculture and manufacturing sector, International Journal of Electrical and Computer Engineering 7: $916-926$. 